\title{
ЛЕЙОМІОМА ТА РЕПРОДУКТИВНА ФУНКЦІЯ. ФРОНТИР РЕПРОДУКТОЛОГІЇ ТА СУЧАСНОГО АКУШЕРСТВА
}

๑д. М. Железов

\section{Одеський національний медичний університет}

РЕЗЮМЕ. Вплив лейоміоми матки на фертильну функцію $є$ складним та залучає численні механізми: від прямого механічного впливу об'єму пухлини на транспорт і імплантацію статевих клітин, впливу на судинну систему матки та на процеси мікроциркуляції до індукції тканиною ЛМ прозапальних цитокінів та впливу на експресію генів (HOXA10, HOXA11, LIF, IL11, BMPR2, BTEB1, ITGB3 тощо) під час «вікна імплантації».

Мета - оцінка реалізації репродуктивної функції у жінок, що страждають на лейоміому матки.

Матеріал і методи. Дослідження виконане на базі КНП «Обласний перинатальний центр» та КНП «Міський пологовий будинок № 5» упродовж 2016-2020рр. Проведений аналіз репродуктивної функції 92 жінок з верифікованою ЛМ, оперованих у обсязі консервативної міомектомії (КМЕ) лапаротомним або лапароскопічним доступом (основна група). Всі вони мали репродуктивні наміри та незмінений оваріально-менструальний цикл після проведеного лікування. Середній вік жінок склав $(34,9 \pm 0,4)$ роки. У якості контролю були обстежені 30 вагітних того ж віку, які на момент взяття на облік не мали значущої соматичної та гінекологічної патології.

Оцінювали частоту спонтанних вагітностей у оперованих жінок, особливості перебігу вагітності (частота загроз переривання вагітності, випадків ЗВУР, ускладнень вагітності та пологів). Упродовж вагітності проводии УЗмоніторинг. Катамнестичний період складав від 2 до 5 років $(\mathrm{Me}=3,5)$.

Результати. Проведення планової міомектомії дозволяє відновити фертильну функцію у 46,7 \% жінок з лМ. Під час вагітності залишкові міоматозні вузли у 58,1 \% жінок були стабільними за розмірами, у 23,3 \% відзначалося збільшення розмірів ЛМ, у 18,6 \% вагітних розмір вузлів зменшився. Неспроможність рубця на матці після КME виявлена у 11,6 \% вагітних. У вагітних з рубцем на матці та залишковими міоматозними вузлами малого розміру частіше реєструються випадки загрози невиношування. У 18 (41,9 \%) жінок основної групи та в 5 (16,7 \%) жінок контрольної груп вдавалися до оперативного розродження, в решти пологи відбулися per vias naturales.

КлючовІ СЛОВА: міома матки; фертильність; прогнозування.

Вступ. Лейоміома матки $є$ одним з найчастіших гінекологічних захворювань у жінок. Ії̈ частота в репродуктивному віці, за даними різних авторів, складає від 10 до 40 \% [1-3]. У жінок при профілактичних оглядах уперше лейоміому матки виявляють у 1-5 \% обстежуваних, серед гінекологічних хворих - до 30-35 \%. Найчастіше ця патологія виявляється у жінок, старших за 35 років (середній вік виявлення лейоміоми матки складає 32-33 роки). Пік захворюваності припадає на вік 35-45 років. В останні роки зростає частота виявлення лейоміоми матки у дівчат і жінок молодого віку (до 20-25 років), що пов'язано, швидше за все, зі спадковим характером захворювання та із впровадженням нових, досконаліших методів діагностики і більшою їх доступністю.

Відповідно до Міжнародної класифікації хворо6 X перегляду лейоміома поділяється на:

- D25 Лейоміома матки;

- D25.0 Підслизова лейоміома матки;

- D25.1 Інтрамуральна лейоміома матки;

- D25.2 Субсерозна лейоміома матки;

- D25.9 Лейоміома матки неуточнена.

Всесвітня організація охорони здоров'я запропонувала класифікувати лейоміоми матки залежно від ступеня їх диференціювання: Лейоміома неуточнена (8890/0) Гістологічні варіанти:

- мітотично активний варіант;
- клітинний варіант (8892/0);

- геморагічний клітинний варіант;

- епітеліоїдний варіант (8891/0);

- міксоїдний варіант (8896/0);

- атиповий варіант (8893/0);

- ліполейоміоматозний варіант (8890/0).

Варіанти росту:

- дифузний лейоміоматоз (8890/1);

- лейоміома, яка розшаровує;

- внутрішньовенозний лейоміоматоз (8890/1);

- лейоміома, яка метастазує (8898/1).

Відповідно класифікації FIGO (відома також як класифікація Мунро), PALM-COEIN категорія лейоміома (L) поділяється на два підтипи [1]:

LSM - для пацієнток з принаймні однією міомою слизової:

Тип 0 Внутрішньопорожнинна лейоміома на ніжці;

Тип 1. <50 \% інтрамуральні розташування;

Тип 2. >50 \% інтрамуральні розташування;

LO - для пацієнток, у яких міоми не уражають порожнину ендометрія.

Тип 3. Контактує з ендометрієм, 100 \% інтрамуральна;

Тип 4. Інтрамуральна;

Тип 5. Субсерозна <50 \% інтрамуральна;

Тип 6. Субсерозна >50 \% інтрамуральна;

Тип 7. Субсерозна лейоміома на ніжці; 
Огляди літератури, оригінальні дослідження, погляд на проблему, випадок з практики, короткі повідомлення

Тип 8. Інші (специфічні, в тому числі шийкова, «паразитарна»).

- гібридні лейоміоми - залучено як ендометрій, так і серозу.

Два номери (категорії), зазначені через дефіс. Згідно з конвенцією, спочатку вказують відношення до ендометрія, потім - до серози. Приклад: 2F5 Субмукозна і субсерозна лейоміома, що виступає менш ніж на половину діаметра в сторону ендометрія і черевної порожнини відповідно [4].

Класифікація Вамстера - де Блока поділяє ЛМ на такі категорії: 0 - $100 \%$ міоми на ніжці знаходяться у порожнині матки, I - більше 50 \% ЛМ знаходяться у порожнині матки, II - менше $50 \%$ міоми знаходяться у порожнині матки (тобто більше $50 \%$ власне у міометрії) [1]. Ця класифікація відповідає першим трьом типам класифікації FIGO $[1,4]$.

Клінічна класифікація лМ є досить неоднорідною: за локалізацією (підочеревинна, міжм'язова, підслизова), має багато проміжних варіантів; за розмірами (невеликі, середні, великі вузли); за розташуванням (дно, тіло, перешийок, шийка матки); за характером (зростання, обумовлене помилковим порушенням кровопостачання, набряком вузла, й істинне - за рахунок процесів проліферації гладком'язових клітин); за морфогістологічними особливостями (проста, проліферувальна, передсаркоматозна і рідкісні варіанти: перитонеальний лейоміоматоз, епітеліоїдна, внутрішньосудинна ЛМ) $[1,2]$.

Вплив ЛМ на фертильну функцію реалізується на декількох рівнях. По-перше, це механічний вплив об'єму пухлини на транспорт та імплантацію статевих клітин, а також структури децидуальної оболонки та фетоплацентарного комплексу. Подруге, це вплив на судинну систему матки та на процеси мікроциркуляції за рахунок стимуляції продукції факторів ангіогенезу та ремоделювання міометрія у зоні розташування ЛМ [5]. Нарешті, доведеною $\epsilon$ індукція тканиною ЛМ прозапальних цитокінів та наявність прямого впливу на експресію генів (HOXA10, HOXA11, LIF, IL11, BMPR2, BTEB1, ITGB3 та ін.) під час «вікна імплантації» $[1,3,5-20]$. Не виключено також, що водночас можуть реалізуватися одразу декілька з цих механізмів [1].

Той факт, що у жінок із міомою знижується фертильність, був встановлений давно. У ретроспективному дослідженні породіль, що мали міому матки, встановлено, що 43 \% жінок мали принаймні дворічну історію безпліддя. Що ще важливіше, частота спонтанних вагітностей після виконання міомектомії значно зростає $[4,19]$. Втім, часто у жінок, оперованих з приводу міоми, виникають інші проблеми, що впливають на фертильну функцію - адже ж формування рубця на матці також може суттєво вплинути на перебіг вагітності, від моменту імплантації до пологів $[1,4-11]$.
Ще одна проблема - вплив ЛМ на успішність IVF. Незважаючи на прогрес у ДРТ, зміна імплантації ембріонів досі вважається відносно низькою. Міома матки $\epsilon$ одним із факторів, які можуть негативно вплинути на результати імплантації та ДРТ [1]. У дослідженні, що включало пацієнток, яким було виконано запліднення in vitro (EK3) / інтрацитоплазматична ін'єкція сперми (ICSI), повідомлялося про достатньо високу частоту захворюваності на міому матки - 26,7 \% [1, 3]. Можливий несприятливий вплив міоми на результат ДРТ можна пояснити зміною судинної перфузії матки, функції ендометрія, скоротливості міометрія, перешкоджанням міграції гамет, зміною експресії генів міометрія/ендометрія, а також зменшенням продукції життєво важливих біологічно активних сполук для сприйнятливості ендометрія $[1,5]$. Крім того, інтенсивність впливу ЛМ на результати ДРТ залежить від їі типу, розміру та кількості міоматозних вузлів $[2,3]$.

Мета - оцінка реалізації репродуктивної функції у жінок, що страждають на лейоміому матки

Матеріал і методи дослідження. Дослідження виконане на базі КНП «Обласний перинатальний центр» та КНП «Міський пологовий будинок № 5» упродовж 2016-2020рр. Проведений аналіз репродуктивної функції 92 жінок з верифікованою ЛМ, оперованих у обсязі консервативної міомектомії (KME) лапаротомним або лапароскопічним доступом, але з наявністю невеликих ЛМ, які не підлягали видаленню під час втручання [1]. Ці жінки склали основну групу. Всі вони мали репродуктивні наміри та незмінений оваріально-менструальний цикл після проведеного лікування. Середній вік жінок склав $(34,9 \pm 0,4)$ роки.

У якості контролю було обстежено 30 вагітних того ж віку, які на момент взяття на облік не мали значущої соматичної та гінекологічної патології.

Всі пацієнтки були обстежені відповідно до наказу МОЗ України N 676 від 31.12.2004 «Про затвердження клінічних протоколів з акушерської та гінекологічної допомоги (із змінами, внесеними згідно з Наказами Міністерства охорони здоров'я N 782 від 29.12.2005, N 624 від 03.11.2008, N 205 від 24.03.2014). Оцінювали частоту спонтанних вагітностей у оперованих жінок, особливості перебігу вагітності (частота загроз переривання вагітності, випадків ЗВУР, ускладнень вагітності та пологів). Впродовж вагітності проводився УЗ-моніторинг. Катамнестичний період складав від 2 до 5 років $(\mathrm{Me}=3,5)$.

Статистичну обробку проводили методами дисперсійного аналізу за допомогою програмного забезпечення Statistica 13.0 (TISCO, США).

Результати й обговорення. Як показали результати спостереження, лише у 43 (46,7 \%) жінок 
Огляди літератури, оригінальні дослідження, погляд на проблему, випадок з практики, короткі повідомлення упродовж перших двох років спостереження виникла спонтанна вагітність. Під час вагітності залишкові міоматозні вузли у $25(58,1 \%)$ жінок були стабільними за розмірами (рис. 1), у 10 (23,3 \%) відзначалося збільшення розмірів лМ більше ніж на $10 \%$ по одному з основних розмірів, у решти 8 (18,6 \%) вагітних розмір вузлів за даними Уз моніторингу навіть дещо зменшився.

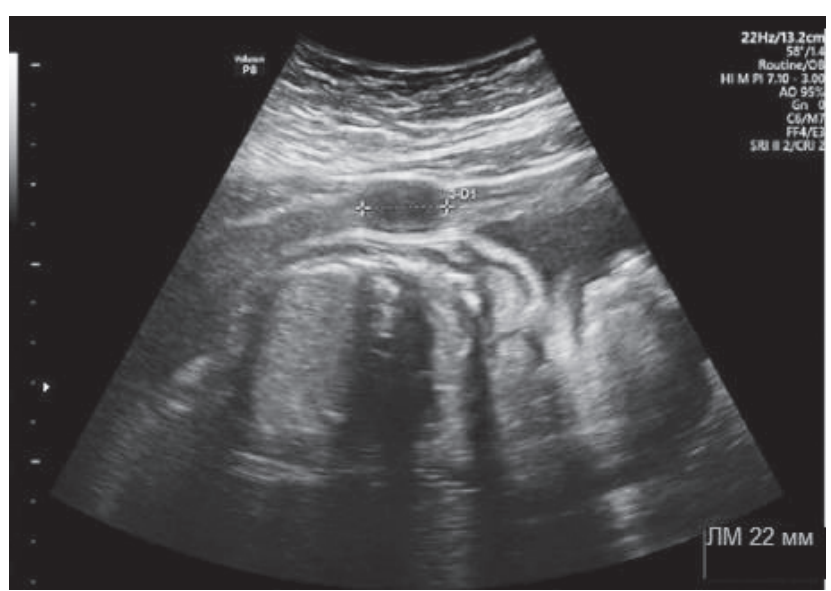

Рис. 1. Лейоміома при вагітності, 27 тиждень гестації.

Вагітні з ЛМ нерідко скаржилися біль внизу живота (36 випадки, або 83,7 \%) та в попереку (30 випадків, а6о 70,0 \%). У контролі ці скарги виникали у 18 (60,0 \%) вагітних, були минущими й менш інтенсивними.

Загроза передчасного переривання вагітності у жінок основної групи виникла у 5 (11,6 \%) випадках у ранні терміни, ще у 9 (20,9 \%) - у більш пізні терміни вагітності. Пастозність гомілок та стоп спостерігалася у 12 (27,9\%) вагітних основної групи та у 3 (10,0 \%) контрольної, помірне підвищення артеріального тиску -у 13 (30,2 \%) основної групи та у 4 (13,3%) контрольної групи.

Ознаки анемії легкого ступеня під час вагітності мали 5 (11,6 \%) вагітних основної групи, се-

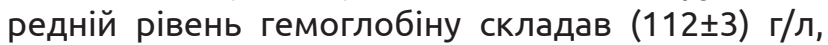
еритроцитів - $(3,43 \pm 0,1) 10^{12} /$ л.

Достатньо частим явищем у вагітних основної групи були аномалії прикріплення плаценти. Їх виявлено у 15 (34,9 \%) пацієнток, причому в структурі ураження переважало низьке розташування пла- центи - 25,6\% випадків. Placenta accrete зареєстрована у 2 (30,0 \%) випадках. У пацієнток контрольної групи аномалій плацентації не визначалося $(p<0,05)$.

у $18(41,9 \%)$ жінок основної групи та у 5 $(16,7 \%)$ контрольної вдавалися до оперативного розродження, в решти пологи відбулися рег vias naturales. Причинами виконання КР були аномалії розташування плаценти (по передній стінці, в ділянці рубця - 10 (23,3 \%), УЗ ознаки неспроможності рубця на матці (5 випадків, або 11,6 \%), а також ранні порушення гемодинамічних показників внутрішньоплацентарного кровотоку, що $\epsilon$ відображенням високого перинатального ризику.

Середні значення БФП склали у вагітних з ЛМ $(8,3 \pm 0,3)$ балів, у контрольній групі - $(8,8 \pm 0,3)$ балів ( $p>0,05)$.

Усі жінки народили живих дітей, пологи у визначений термін відбулися у 40 (93,0 \%) жінок основної групи та у 29 (96,7%) контрольної, у 4 жінок відбулися передчасні пологи. При оцінці новонароджених за шкалою Апгар в основній групі на першій хвилині оцінка склала в середньому $(6,9 \pm 0,3)$ бали, в контрольній - $(7,1 \pm 0,4)$ бали. На п'ятій хвилині оцінка за Апгар склала відповідно $(7,4 \pm 0,3)$ та $(7,9 \pm 0,4)$ балів.

Висновки. 1. Проведення планової міомектомії дозволяє відновити фертильну функцію у $46,7 \%$ жінок із ЛМ.

2. Під час вагітності залишкові міоматозні вузли у 58,1 \% жінок були стабільними за розмірами, у 23,3 \% відзначалося збільшення розмірів лМ, у 18,6 \% вагітних розмір вузлів зменшився.

3. Неспроможність рубця на матці після КME виявлена у $11,6 \%$ вагітних.

4. У вагітних із рубцем на матці та залишковими міоматозними вузлами малого розміру частіше реєструються випадки загрози невиношування.

5. У $18(41,9 \%)$ жінок основної групи та у 5 $(16,7 \%)$ контрольної вдавалися до оперативного розродження, в решти пологи відбулися per vias naturales.

Перспективи подальших досліджень пов'язані з оцінкою впливу лейоміоми матки на процедури IVF у жінок пізнього репродуктивного віку.

3. Zepiridis L. I. Infertility and uterine fibroids / L. I. Zepiridis, G. F. Grimbizis, B. C. Tarlatzis // Best Pract. Res. Clin. Obstet. Gynaecol. - 2016. - Vol. 34. - P. 66-73.

4. Minimally invasive surgery for uterine fibroids / Y. Wang, S. Zhang, C. Li [et al.] // Ginekol. Pol. - 2020. Vol. 91 (3). - P. 149-157.

5. Association of uterine fibroids with birthweight 
Огляди літератури, оригінальні дослідження, поглядн and gestational age / S. K. Zhao, P. Wu, S. H. Jones [et al.] // Ann. Epidemiol. - 2020. - Vol. 50. - P. 35-40.

6. Short-term quality of life after myomectomy for uterine fibroids from the COMPARE-UF Fibroid Registry / S. K. Laughlin-Tommaso, D. Lu, L. Thomas [et al.] // Am. J. Obstet. Gynecol. - 2020. - Vol. 222 (4). - P. 345-345.

7. Myomectomy: It's Role in Infertility. - 2011. - URL: https://www.contemporaryobgyn.net/view/ myomectomy-its-role-infertility.

8. Epidemiology of uterine fibroids: a systematic review / E. A. Stewart, C. L. Cookson, R. A. Gandolfo, R. Schulze-Rath // BJOG. - 2017. - Vol. 124 (10). - P. 1501-1512.

9. Baranov V. S. Pathogenomics of uterine fibroids development / V. S. Baranov, N. S. Osinovskaya, M. I. Yarmolinskaya // Int. J. Mol. Sci. - 2019. - Vol. 20 (24). - P. 6151.

10. Whynott R. M. The effect of uterine fibroids on infertility: a systematic review / R. M. Whynott, K. C. C. Vaught, J. H. Segars // Semin. Reprod. Med. - 2017. - Vol. 35 (6). P. 523-532.

11. Ikhena D. E. Literature review on the role of uterine fibroids in endometrial function / D. E. Ikhena, S. E. Bulun // Reprod. Sci. - 2018. - Vol. 25 (5). - P. 635-643.

12. Integrated epigenome, exome, and transcriptome analyses reveal molecular subtypes and homeotic transformation in uterine fibroids / J. W. George, H. Fan, B. Johnson [et al.] // Cell Rep. - 2019. - Vol. 29 (12). - P. 4069-4085.

13. Fibroids that do not distort the uterine cavity and IVF success rates: an observational study using extensive matching criteria / G. Christopoulos, A. Vlismas, R. Salim [et al.] // BJOG. - 2017. - Vol. 124 (4). - P. 615-621.

14. Alterations in uterine hemodynamics caused by uterine fibroids and their impact on in vitro fertilization outcomes / J. W. Moon, C. H. Kim, J. B. Kim [et al.] // Clin. Exp. Reprod. Med. - 2015. - Vol. 42 (4). - P. 163-168.

15. van der Veen F. Fibroids and IVF: retrospective studies or randomised clinical trials? / F. van der Veen // BJOG. - 2017. - Vol. 124 (4). - P. 622.

16. Proinflammatory mediators and reproductive failure in women with uterine fibroids / O. Sevostyanova, T. Lisovskaya, G. Chistyakova [et al.] // Gynecol. Endocrinol. 2020. - Vol. 36 (Sup1.). - P. 33-35.

17. Khaw S. C. Systematic review of pregnancy outcomes after fertility-preserving treatment of uterine fibroids / S. C. Khaw, R. A. Anderson, M. W. Lui // Reprod. Biomed. Online. - 2020. - Vol. 40 (3). - P. 429-444.

18. Uterine fibroids increase time to pregnancy: a cohort study / K. Karlsen, O. Mogensen, P. Humaidana [et al.] // Eur. J. Contracept. Reprod. Health Care. - 2020. - Vol. 25 (1). P. 37-42.

19. Zhelezov D. M. Revisiting the peculiarities of pregnancy and childbirth in women with uterine scarring syndrome / D. M. Zhelezov, G. S. Manasova, N. V. Kuzmin // Likarska Sprava. - 2020. - No. 1-2. - P. 50-56.

20. Al-Hendy A. Uterine fibroids: burden and unmet medical need / A. Al-Hendy, E. R. Myers, E. Stewart // Semin. Reprod. Med. - 2017. - Vol. 35 (6). - P. 473-480.

\section{REFERENCES}

1. Botros, R.M.B. Rizk, Khalaf, Y., \& Borahay, M.A (2021). Fibroids and Reproduction Boca Raton: CRC press, NY https://doi.org/10.1201/9780203728987

2. Parazzini, F., Tozzi, L., \& Bianchi, S. (2016). Pregnancy outcome and uterine fibroids. Best Pract. Res. Clin. Obstet. Gynaecol., 34, 74-84. DOI: 10.1016/j.bpobgyn.2015.11.017

3. Zepiridis, L.I., Grimbizis, G.F., \& Tarlatzis, B.C. (2016). Infertility and uterine fibroids. Best Pract Res Clin Obstet Gynaecol., 34, 66-73. DOI: 10.1016/j.bpobgyn.2015.12.001

4. Wang, Y., Zhang, S., Li, C., Li, B., \& Ouyang, L. (2020). Minimally invasive surgery for uterine fibroids. Ginekol. Pol., 91 (3), 149-157. DOI: 10.5603/GP.2020.0032

5. St Peter, C.C., Shuler, N.J., Jones, S.H., Bradtke, S., Hull, S.L., Browning, B., \& Petitto, C. (2020). Association of uterine fibroids with birthweight and gestational age. Ann. Epidemiol., 50, 35-40. DOI: 10.1016/j.annepidem.2020.06.012

6. Laughlin-Tommaso, S.K., Lu, D., Thomas, L., Diamond, M.P., Wallace, K., Wegienka, G., \& Myers, E.R. (2020). Short-term quality of life after myomectomy for uterine fibroids from the COMPARE-UF Fibroid Registry. Am. J. Obstet. Gynecol., 222 (4), 345-345. DOI: 10.1016/j.ajog. 2019.09.052

7. (2011). Myomectomy: It's Role in Infertility. Retrieved from: https://www.contemporaryobgyn.net/view/ myomectomy-its-role-infertility

8. Stewart, E.A., Cookson, C.L., Gandolfo, R.A., \& Schulze-Rath, R. (2017). Epidemiology of uterine fibroids: a systematic review. BJOG, 124 (10), 1501-1512. DOI: $10.1111 / 1471-0528.14640$

9. Baranov, V.S., Osinovskaya, N.S., \& Yarmolinskaya, M.I. (2019). Pathogenomics of uterine fibroids de-

velopment. Int. J. Mol. Sci., 20 (24), 6151. DOI: 10.3390/ ijms20246151. DOI: 10.3390/ijms20246151

10. Whynott, R.M., Vaught, K.C.C., \& Segars, J.H. (2017). The effect of uterine fibroids on infertility: a systematic review. Semin. Reprod. Med., 35 (6), 523-532. DOI: $10.1055 / \mathrm{s}-0037-1607295$

11. Ikhena, D.E., \& Bulun, S.E. (2018). Literature review on the role of uterine fibroids in endometrial function. $R e$ prod. Sci., 25 (5), 635-643. DOI: 10.1177/1933719117725827

12. George, J.W., Fan, H., Johnson, B., Carpenter, T.J., Foy, K.K., Chatterjee, A., \& Teixeira, J.M. (2019). Integrated epigenome, exome, and transcriptome analyses reveal molecular subtypes and homeotic transformation in uterine fibroids. Cell Rep., 29 (12), 4069-4085. DOI: 10.1016/j. celrep.2019.11.077

13. Christopoulos, G., Vlismas, A., Salim, R., Islam, R., Trew, G., \& Lavery, S. (2017). Fibroids that do not distort the uterine cavity and IVF success rates: an observational study using extensive matching criteria. BJOG, 124 (4), 615-621. DOI: 10.1111/1471-0528.14362

14. Moon, J.W., Kim, C.H., Kim, J.B., Kim, S.H., Chae, H.D., \& Kang, B.M. (2015). Alterations in uterine hemodynamics caused by uterine fibroids and their impact on in vitro fertilization outcomes. Clin. Exp. Reprod. Med., 42 (4), 163-168. DOI: 10.5653/cerm.2015.42.4.163

15. van der Veen, F. (2017). Fibroids and IVF: retrospective studies or randomised clinical trials? BJOG, 124 (4), 622. DOI: 10.1111/1471-0528.14461

16. Sevostyanova, O., Lisovskaya, T., Chistyakova, G., Kiseleva, M., Sevostyanova, N., Remizova, I., \& Buev, Y. 
Огляди літератури, оригінальні дослідження, погляд на проблему, випадок з практики, короткі повідомлення (2020). Proinflammatory mediators and reproductive failure in women with uterine fibroids. Gynecol. Endocrinol., 36 (1), 33-35. DOI: 10.1080/09513590.2020.1816726

17. Khaw, S.C., Anderson, R.A., \& Lui, M.W. (2020). Systematic review of pregnancy outcomes after fertilitypreserving treatment of uterine fibroids. Reprod. Biomed. Online, 40 (3), 429-444. DOI: 10.1016/j.rbmo.2020.01.003

18. Karlsen, K., Mogensen, O., Humaidana, P., Kesmodel, U.S., \& Ravn, P. (2020). Uterine fibroids increase time to

pregnancy: a cohort study. Eur. J. Contracept. Reprod. Health Care, 25 (1), 37-42. DOI: 10.1080/13625187.2019.1699047

19. Zhelezov, D.M., Manasova, G.S., \& Kuzmin, N.V. (2020). Revisiting the peculiarities of pregnancy and childbirth in women with uterine scarring syndrome. Likarska Sprava, 1-2, 50-56.

20. Al-Hendy, A., Myers, E.R., \& Stewart, E. (2017). Uterine fibroids: burden and unmet medical need. Semin. Reprod.Med., 35(6), 473-480.DOI:10.1055/s-0037-1607264

\section{ЛЕЙОМИОМА И РЕПРОДУКТИВНАЯ ФУНКЦИЯ. ФРОНТИР РЕПРОДУКТОЛОГИИ И СОВРЕМЕННОГО АКУШЕРСТВА}

\section{Одесский национальный медицинский университет}

๑Д. М. Железов

РЕЗЮмЕ. Влияние миомы матки на фертильную функцию является сложным и привлекает многочисленные механизмы - от прямого механического воздействия объема опухоли на транспорт и имплантацию половых клеток, влияния на сосудистую систему матки и на процессы микроциркуляции индукции тканью ПМ провоспалительных цитокинов и влияния на экспрессию генов (HOXA10, HOXA11, LIF, IL11, BMPR2, BTEB1, ITGB3 и др.) во время «окна имплантации».

Цель - оценка реализации репродуктивной функции у женщин, страдающих лейомиомой матки.

Материал и методы. Исследование выполнено на базе КНП «Областной перинатальный центр» и КНП «Городской родильный дом № 5» в течение 2016-2020 гг. Проведен анализ репродуктивной функции 92 женщин с верифицированной ПМ, оперированных в объеме консервативной миомэктомии (KME) лапаротомным или лапароскопическим доступом (основная группа). Все они имели репродуктивные намерения и неизмененный овариально-менструальный цикл после проведенного лечения. Средний возраст женщин составил $(34,9 \pm 0,4)$ года. В качестве контроля были обследованы 30 беременных того же возраста, которые на момент постановки на учет не имели значимой соматической и гинекологической патологии. Оценивали частоту спонтанных беременностей у оперированных женщин, особенности течения беременности (частота угроз прерывания беременности, случаев задержки внутриутробного развития, осложнений беременности и родов). В течение беременности проводился УЗИ мониторинг. Катамнестический период составлял от 2 до 5 лет $(\mathrm{Me}=3,5)$.

Результаты. Проведение плановой миомэктомии позволяет восстановить фертильную функцию у 46,7 \% женщин с ПМ. Во время беременности остаточные миоматозные узлы в 58,1 \% женщин были стабильными по размерам, у 23,3 \% отмечалось увеличение размеров ПМ, у 18,6 \% беременных размер узлов уменьшился. Несостоятельность рубца на матке после КМЕ обнаружена у 11,6 \% беременных. У беременных с рубцом на матке и остаточными миоматозными узлами малого размера чаще регистрируются случаи угрозы невынашивания. У 18 $(41,9$ \%) женщин основной группы и у 5 (16,7 \%) контрольной прибегали к оперативному родоразрешению, у остальных роды произошли рег vias naturales.

КЛЮЧЕВЫЕ СЛОВА: миома матки; фертильность; прогнозирование.

\section{LEIOMYOMA AND REPRODUCTIVE FUNCTION. FRONTIER OF REPRODUCTOLOGY AND MODERN OBSTETRICS}

@D. M. Zhelezov

\section{Odesa National Medical University}

SUMMARY. The effect of uterine fibroids on fertility is complex and involves numerous mechanisms from the direct mechanical effect of tumor volume on the transport and implantation of germ cells, the effect on the uterine vascular system and on the processes of microcirculation of PM tissue induction of pro-inflammatory cytokines and the effect on gene expression (HOXA10, HOXA11, LIF, IL11, BMPR2, BTEB1, ITGB3, etc.) during the "implantation window".

The aim - to assess the implementation of reproductive function in women with uterine leiomyoma

Material and Methods. The study was performed on the basis of KNP "Regional Perinatal Center" and KNP "City Maternity Hospital No. 5" during 2016-2020. All of them had reproductive intentions and an unchanged ovarian-menstrual cycle after treatment. The mean age of women was $34.9 \pm 0.4$ years. As a control, 30 pregnant women of the same age were examined, who at the time of registration did not have significant somatic and gynecological pathology. 
Огляди літератури, оригінальні дослідження, погляд на проблему, випадок з практики, короткі повідомлення

The frequency of spontaneous pregnancies in operated women, features of pregnancy (frequency of threats of abortion, cases of ZVUR, complications of pregnancy and childbirth) were evaluated. Ultrasound monitoring was performed during pregnancy. The follow-up period ranged from 2 to 5 years $(\mathrm{Me}=3.5)$.

Results. Planned myomectomy restores fertile function in $46.7 \%$ of women with LM. During pregnancy, residual myomas in $58.1 \%$ of women were stable in size, in $23.3 \%$ there was an increase in the size of the LM, in $18.6 \%$ of pregnant women the size of the nodes decreased. Failure of the scar on the uterus after CME was found in $11.6 \%$ of pregnant women. In pregnant women with a scar on the uterus and residual fibroids of small size are more likely to register cases of threat of miscarriage. In 18 (41.9\%) women of the main group and 5 (16.7 \%) control resorted to operative delivery, in the remaining births occurred per vias naturales.

KEY WORDS: uterine fibroids; fertility; prognosis. 